\title{
Bermain Peran : Sebuah Metode Pembelajaran Untuk Mengembangkan Keterampilan Sosialisasi Anak Autis
}

\author{
Mega Iswari ${ }^{1}$, Elsa Efrina ${ }^{2}$, Kasiyati $^{3}$ Arisul Mahdi $^{4}$ \\ ${ }^{123}$ Universitas Negeri Padang,Indonesia \\ Email:mega_iswari@yahoo.com
}

\section{INFORMASI ARTIKEL}

Terkirim 31 Juli 2018

Revisi 23 Agustus 2018

Diterima 29 November 2018

\section{Katakunci:}

Autism

Socialization

Role Playing

\begin{abstract}
Abstrak
Artikel ini membahas tentang metode bermain peran untuk mengembangkan sosialisasi anak autis. Empat sekolah inklusif yang memiliki anak autis dipilih dalam studi ini. Jumlah partisipan yang terlibat yaitu tujuh orang anak autis, tujuh orang tua dari anak autis, empat orang kepala sekolah, empat orang guru kelas dan empat orang guru pendidik khusus. Pengumpulan data dilakukan secara kualitatif melalui kegiatan wawancara dan observasi. Data yang dikumpulkan berupa kemampuan dasar sosialisasi anak autis di sekolah dan informasi mengenai potensi sekolah yang kemudian dijadikan dasar untuk merancang metode bermain peran yang akan dilaksanakan mengembangkan kemampuan sosial anak autis di sekolah inklusif. Hasilnya, kemampuan sosial anak autis terlihat rendah, namun mereka rata-rata memiliki intelektual yang bagus. Dari dukungan lingkungan, seperti orang tua, guru kelas, guru pendidik khusus dan kepala sekolah memiliki potensi untuk berkoordinasi dalam melaksanakan metode bermain peran untuk mengembangkan kemampuan sosial anak autis.
\end{abstract}

(D) (2) This is an open access article distributed under the Creative Commons 4.0 Attribution License, This license lets others remix, tweak, and build upon your work even for commercial purposes, as long as they credit you and license their new creations under the identical terms $\odot 2018$ by author and UniversitasNegeri Padang.

\section{Pendahuluan}

Autisme berasal dari kata "Auto"yang mempunyai arti "sendiri" dimana kesendrian diartikan sebagai yang memiliki suatu kelainan perkembangan yang sangat besar mempengaruhi anak secara mendalam. Kelainan tersebut mengakibatkan anak mengalami gangguan pada interaksi sosial, sensorik motorik, komunikasi, bahasa dan bicara, serta keterlambatan dalam bidang kognitif. Semua hambatan tersebut berdampak pada rendahnya kemampuan bersosialisasi anak autis.

Mengingat perkembangan layanan pendidikan yang semakin terbuka, anak autis pun sudah mulai banyak yang mengakses pendidikan dalam seting inklusif di sekolah reguler. Artinya, seorang anak autis yang bersekolah di sekolah inklusif harus memiliki kemampuan berkomunikasi yang baik. Namun faktanya, kebanyakan anak atis yang bersekolah di sekolah inklusif masih rendah kemampuan dalam bersosialisasi. Hal ini disinyalir akan berdampak pada perkembangan sosial dan pencapaian hasil belajar anak autis di sekolah inklusif.

Teknik dan model intervensi yang dilakukan untuk mengembangkan keterampilan sosial pada anak autis yang sudah diterapkan cukup beragam. Metode Lovaas cukup efektif diterapkan untuk mengembangkan keterampilan sosial anak autis, namun metode ini harus memiliki komitmen pelaksanaan selama 40 jam dalam seminggu, artinya, semakin kurang dari 40 jam maka akan semakin minim perkembangan yang didapatkan (Suryawati, 2010). sebuah penelitian lain tentang efektifitas metode ABA (Applyed Behavior Analisys) di sebuah Sekolah Luar Biasa (SLB) juga menunjukkan pengaruh yang cukup untuk mengembangkan sosial anak autis (Hardani \& Rahmawati, 2007). Keterbatasan dari penelitian ini dilakukan di lingkungan SLB bukan dalam konteks di lingkungan yang lebih inklusif.

Salah satu cara yang dapat digunakan untuk meningkatkan keterampilan sosial anak autis melalui kegiatan bermain peran. Metode bermain peran disebut juga dengan metode sosiodrama yang sering digunakandalam mengajarkan nilai-nilai dan memecahkan masalah-masalah yang dihadapi dalam hubungan sosial dengan orang-orang dilingkungan keluarga, sekolah, maupun masyarakat (Ibrahim \& Syaodih, 1996). Penerapan metode ini bagi anak reguler dianggap berhasil untuk meningkatkan kemampuan anak dalam bersosialisasi dengan lingkungannya.

Djamarah dan Zain (1996) mengemukakan kelebihan metode sosiodrama atau bermain peran, sebagai berikut:

1. Anak didik melatih dirinya untuk melatih, memahami, dan mengingat isi bahan yang akan didramakan.

2. Anak didik akan terlatih untuk berinisiatif dan berkreatif. Pada waktu main drama para pemain dituntut untuk mengemukakan pendapatnya sesuai dengan waktu yang tersedia.

3. Bakat yang terdapat pada siswa dapat dipupuk sehingga memungkinkan akan muncul atau tumbuh bibit seni drama dari sekolah.

4. Kerjasama antar pemain dapat ditumbuhkan dan dibina sebaik-baiknya.

5. Siswa memperoleh kebiasaan untuk menerima dan membagi tanggungjawab dengan sesamanya.

6. Bahasa lisan siswa dapat dibina menjadi bahasa yang baik agar mudah dipahami orang lain.

Artikel ini membahas tentang kemampuan sosialisasi anak autis di sekolah inklusif serta menggali potensi yang ada di lingkungan anak untuk mengembangkan kemampuan sosial anak autis melalui kegiatan bermain peran. Diharapkan tulisan ini juga menjadi bahan acuan untuk melaksanakan 
layanan pendidikan anak autis di sekolah inklusif, dan sebagai upaya untuk memotivasi guru agar membantu anak autis supaya mampu mengembangkan kemampuan sosialnya melalui kegiatan bermain peran dalam berkomunikasi, berinteraksi, dan bersosialisasi bersama teman sebaya, guru, warga sekolah dan lingkungan masyarakat.

\section{Metode}

Sebanyak tujuh orang anak autis, tiga orang guru pendidik khusus, empat orang kepala sekola dari 4 sekolah penyelenggara pendidikan inklusif dan tujuh orang tua dari anak autis berpartisipasi dalam penelitian ini. Pemilihan sekolah tempat penelirian menggunakan purposive sampling, dengan pertimbangan sekolah tersebut adalah sekolah yang menerima dan melayani pendidikan bagi anak autis dalam seting inklusif.

Pengumpulan databerfokus pada kondisi objektif kemampuan sosial anak autis dan potensi sekolah serta orang tua untuk mengembangkan kemampuan sosial anak autis melalui kegiatan bermain peran. Pendekatan yang digunakan yaitu pendekatan penelitian kualitatif melalui observasi dan wawancaradan studi dokumentasi. Observasi digunakan untuk mengamatiketerampilan sosial anak autis dalam berinteraksi, berkomunikasi dan bersosialisasi dengan siswa reguler lainnya. Pengamatan dilakukan saat anak autis mengikuti pembelajaran di kelas dan juga waktu bermain pada waktu istirahat bersama teman sebayanya. Wawancara untuk mengetahui penerapan model bermain peran bagi autis dalam meningkatkan keterampilan sosialnya. Wawancara dilakukan dengan kepala sekolah, guru pendidik khusus, dan para orang tua dari anak autis.

\section{Hasil}

1 Kemampuan anak autis dalam keterampilan sosial melalui bermain peran di sekolah dasar penyelenggara pendidikan inklusi

Berdasarkan hasil pengamatan dan wawancara dengan guru dan teman sebaya, terhadap kemampuan sosial anak autis di beberapa sekolah penyelenggara pendidikan inklusif, diketahui bahwa kemampuan anak autis secara umum memiliki ciri khas yang sama namun kemampuan sosialnya beragam, hal ini disebabkan karena kondisi anaknya juga beragam. Ada anak yang sudah mau berinteraksi, namun ada juga yang masih minim interaksinya. Demikian juga dengan kemampuan komunikasinya dengan orang lain, baik dengan orang tua, guru, teman sebaya maupun dengan orang lain di sekitarnya. Hal ini terlihat pada saat pembelajaran berlangsung di kelas maupun pada jam istirahat. Melalui pengamatan saat pembelajaran berlangsung diketahui anak anak autis yang terlihat acuh tak acuh dalam mengikuti pelajaran, ada juga yang memperlihatkan emosi yang kurang terkendali sehingga terkadang mengganggu teman teman di kelas. Pada saat jam istirahat, terlihat kemampuan sosial anak autis yang juga beragam. Ada yang sudah mampu berinteraksi secara baik dengan teman-temannya, ada juga yang belum. Bagi anak autis yang sudah dapat berinteraksi, terlihat ketika jam istirahat, mereka bermain secara wajar dan tidak mengganggu teman-temannya. Sementara itu, anak autis yang kemampuan sosialnya masih rendah, terlihat pada jam istirahat mereka masih menyendiri, tidak acuh dengan kegiatan bermain yang dilakukan teman-temannya. Ada juga yang sampai mengganggu dan bertengkar (memukul dan menendang) temannya, hal ini terjadi jika mereka merasa tidak nyaman atau terganggu oleh teman-temannya, sehingga emosinya tidak terkendali.

Dalam hal kemampuan komunikasi dalam berinteraksi sosial, ada anak autis yang telah mempunyai kemampuan bicara dan bahasa yang baik meskipun masih memiliki kemampuan sosial yang minim, namun ada juga yang belum bisa bicara. Hal ini terlihat pada saat berbelanja di kantin sekolah pada jam istirahat sekolah. Ada anak yang langsung berbelanja ke kantin sekolah pada saat bel berbunyi, mengambil makanan yang dia inginkan, dan langsung membayar ke kasir tanpa berbicara sepatah katapun. Namun ada juga yang dapat menjawab jika ada yang bertanya namun hanya dengan satu dua kata saja. Misalnya ada teman yang bertanya, "kamu beli apa?", dijawab oleh anak autis, "bakwan”, dan tidak ada lagi interaksi dan komunikasi yang lain. Anak autis hanya menggunakan kata yang singkat saja seperti "sudah", "iya", "enak" dan "itu". Sembari perhatiannya tidak fokus pada orang yang mengajaknya untuk berkomunikasi.

Pada anak autis perkembangan sosial mereka sangat dipengaruhi oleh lingkungan sosial dan anggota keluarga, serta masyarakat di lingkungan sekolah. Apabila lingkungan ini dapat memberikan perhatian pada anak autis maka diasumsikan perkembangan sosial anak autis akan tercapai dengan baik. Anak autis yang mengikuti pendidikan di sekolah dasar penyelenggara pendidikan inklusi adalah anak-anak yang dianggap mampu untuk mengikuti pendidikan danal seting inklusif dengan modalitas kemampuan mendengar, mengikuti dan memahami pembicaraan yang cukup baik.

Kemampuan anak autis dalam berinteraksi sangat beragam bagi anak yang suka menyendiri memiliki kemampuan berkomunikasi dan berkonsentrasi begitu lemahnya, sehingga sangat jarang terjadi anak autis memulai menyapa atau mengajak seseorang untuk berkomunikasi. Oleh karena itu temantemannyalah yang selalu menyapa dan mengajaknya untuk bermain. Begitu juga kemampuan anak autis dalam berkomunikasi bersama dengan temannya yaitu sangat jarang sekali anak autis mau bertanya tentang soal-soal latihan yang dibutuhkan untuk menjawab pertanyaan, sehingga apabila anak autis tidak dapat menjawab soal-soal latihan yang diberikan guru. Maka soal-soal itu dibiarkan saja dan tidak dijawabnya.

\section{Permasalahan Pembelajaran Anak Autis dalam keterampilan sosial di sekolah dasar penyelenggara pendidikan inklusi}

Seiring dengan kemampuan sosial anak autis yang telah dipaparkan sebelumnya, diketahui juga bahwa kemampuan sosial dan komunikasi yang beragam pada anak autis juga menimbulkan permasalahan dalam pembelajaran. Permasalahan yang sering muncul pada anak autisme yang dapat mempengaruhi atau menjadi masalah pula dalam proses pembelajarannya, diantaranya yaitu: masalah perilaku yang sering muncul seperti sering membeo atau mengulangi kata-kata yang ia dengar, memukul-mukul meja, berteriak tanpa sebab yang jelas. Selain itu hambatan yang terjadi pada anak autis yaitu sering mengganggu teman, tidak mengerti pembicaraan orang lain, mereka hanya dapat berkomunikasi dengan kata-kata yang sangat singkat, kurang fokus dalam pembelajaran, tantrum atau marah dan menyakiti diri sendiri. Namun ada juga anak autis yang sering menyendiri, asyik dengan dunianya sendiri, seperti asyik memegang benda-benda yang berputar, memegang bola, sementara teman-teman reguler lainnya sibuk dengan sesama temantemannya yang lain sesama reguler.

\section{Kompetensi guru}

Kompetensi guru secara garis besar merupakan kemampuan dan kewenangan yang harus dimiliki seseorang untuk memangku jabatan guru sebagai profesi. Seorang guru diwajibkan memiliki empat kompetensi, yaitu kompetensi kepribadian, kompetensi pedagogik, kompetensi profesional dan kompetensi sosial. Dalam hal kompetensi profesional, seorang guru harus memiliki subkompetensi yaitu memahami peserta didik, merancang pembelajaran, melaksanakan pembelajaran, serta merancang dan melaksanakan pembelajaran.

Memahami peserta didik merupakan salah satu yang harus dimiliki oleh seorang guru Sekolah Dasar (SD), maupun guru pendidikan khusus (GPK). Dalam hal ini, guru harus mampu memahami peserta didiknya termasuk peserta didik yang memiliki kebutuhan khusus, dalam hal ini peserta didik autis. Dalam hal merancang dan melaksanakan pembelajaran, guru SD dihadapkan pada permasalahan-permasalahan untuk merencanakan dan memberikan bimbingan serta layanan pembelajaran yang terintegrasi pada anak autis dengan anak reguler lainnyadalam melatih bersosialisasidan berkomunikasi.

Guru berusaha untuk mengembangkan keterampilan sosial pada anak autis dan memberi pengertian pada anak-anak reguler lainnya agar mereka menerima kehadiran dari anak autis di sekolahnya. Hal ini tidak gampang bagi guru untuk memberikan pemahaman agar siswa reguler menerima dan memahami perilaku anak autis. Belum lagi dalam memberikan pembelajaran sangat sulit bagi guru meyampaikan materi-materi yang dipajari. Namun bagi orang tua yang menginginkan anaknya dibantu dalam pembelajaran, maka orang tua memfasilitasi guru yang berlatar belakang pendidikan luar biasa untuk dapat mendampingi anaknya belajar disekolah guru ini disebut juga dengan GPK.

4 Hal yang perlu diperhatikan guru dan kepala sekolah

Hal-hal yang perlu diperhatikan guru dan kepala sekolah tentang keterampilan sosial bagi anak autis berdasarkanhasil observasi dan wawancara pada guru 
dan kepala sekolah ternyata guru telah memahami siapa anak autis, bagaimana anak autis, karakteristik anak autis, klasifikasi penyandang autis. Klasifikasi ini semua perlu diperhatikan oleh guru, baik guru pembimbing khusus, maupun guru kelas selalu berdiskusi dengan guru pembimbing khusus dalam memberikan layanan pendidikan di sekolah dalam proses pembelajaran. Hal ini terkait juga dengan kompetensi seorang guru dalam hal memahami peserta didiknya.

Dukungan orang tua juga mempengaruhi peningkatan keterampilan sosial anak autis. Berdasarkan hasil wawancara dengan kepala sekolah dan guru di sekolah penyelenggara pendidikan inklusi, ternyata orang tua memiliki keinginan untuk memajukan penyelenggara pendidikan bagi autis, karena orang tua juga terdiri dari berbagai macam latarbelakang pendidikan seperti ada dosen, polisi, Pegawai Negeri Sipil (PNS) dan lain sebagainya, sehingga orang tua ikut memberikan sumbangan pemikiran, tenaga, dan materi demi kelancaran proses pembelajaran di sekolah demi mendukung anak autis untuk mampu mandiri di lingkungan masyarakat di kemudian hari.

\section{Dukungan orang tua}

Dukungan yang dapat orang tua berikan diantaranya dari segi materi seperti memberikan honor GPK yang tidak terlalu minim, memberikan buku dan media pembelajaran yang sesuai dengan karakteristik anak autis, dukungan dari segi pemikiran dapat berupa mengupayakan anak untuk mengikuti proses terapi, orang tua mendukung untuk menerima siswa baru yang mengalami autis, sedangkan dukungan dari segi tenaga dapat berupa penyediaan GPK dan juga terapis untuk anak autis sehingga anak autis sudah memiliki kontak mata dan ketahanan duduk sebelum mengikuti proses pembelajaran.

\section{Pembahasan}

1. Hambatan yang terjadi pada anak autis dalam meningkatkan keterampilan sosial

Anak mengalami hambatan yang sangat beragam diantaranya ada yang komunikasinya sangat sedikit dengan teman sebayanya ataupun dengan guru. Kemudian pada saat berkomunikasi anak autis tidak mempolakan arah pembicaraannya, sehingga tidak jelas komunikasi yang disampaikan, kadangkadang anak autis berkomunikasi sambil tidak memperhatikan lawan bicaranya. Salah satu ciri-ciri dari anak autis adalah memang sulit untuk berkomunikasi, bahkan sering terjadi pengulangan kata yang diucapkan. Begitu juga dalam berinteraksi dengan teman sebaya dan guru. Anak autis lebih senang untuk menyendiri, mereka hanya mau berinteraksi apabila teman sebayanya lebih aktif untuk berinteraksi, baik di dalam kelas maupun di luar kelas, baru mau mereka mau untuk berinteraksi. Jadi untuk anak autis orang-orang disekitarnyalah yang harus lebih peduli untuk mengajak anak berinteraksi seperti menyapa, menolong, berinteraksi, dan berkomunikasi yang lain.

Demikian pula dengan bentuk-bentuk komunikasi atau kata-kata yang diucapkan pada saat berkomunikasi antara anak autis dengan anak reguler yang sebayanya hanya menggunakan kalimat-kalimat yang sangat pendek yaitu seperti "tidak mau, ini, itu, iya". Dan kadang-kadang sering terjadi pengulangan kata seperti "iya, iya, iya", "tidak, tidak, tidak", sembari anak autis tidak fokus dalam mengucapkannya. Kata-kata yang keluar dari mulutnya. Kadangkadang anak autis ini sering membeo ketika dia mendengar kata dari guru atau dari teman sebayanya, sehingga anak autis sering tidak mau berkomunikasi dengan temannya, karena memang komunikasi adalah hambatan yang paling utama dialami oleh anak autis, sehingga guru kelaspun mengalami kendala dalam berkomunikasi. Maka di sekolah penyelenggara pendidikan inklusi, kepala sekolah atau orang tua mencarikan guru pendamping khusus untuk membantu anak dalam keterampilan sosialdan dalam proses pembelajarannya di kelas.

2. Pemahaman guru kelas dan kepala sekolah terhadap anak autis dalam keterampilan sosial.

Berdasarkan hasil wawancara pada guru kelas dan kepala sekolah tentang keterampilan sosial yang harus dimiliki oleh anak autis ternyata guru dan kepala sekolah cukup mengetahui tentang anak autis, karakteristik anak autis, karena guru merupakan faktor yang paling penting dan paling utama dalam menyelenggarakan pendidikan di sekolah dasar penyelenggara pendidikan inklusi. Guru hendaknya memiliki berbagai kompetensi dalam rangka mengembangkan keterampilan sosial anak autis secara utuh sesuai dengan tujuan pendidikan agar anak autis dapat berkembang sesuai dengan anak reguler lainnya. Sehingga mereka mampu juga melanjutkan pendidikan ke jenjang yang lebih tinggi dan memiliki kemampuan berkomunikasi dengan baik, berinteraksi dengan teman sebaya di sekolah, dengan warga disekolah, orang tua dan keluarga serta masyarakat.

3. Guru kelas memahami tentang bermain peran dalam meningkatkan keterampilan sosial anak autis di sekolah dasar

Dari hasil observasi dan wawancara yang dilakukan pada guru, ternyata guru hanya bertanya dan menyapa, sehingga anak hanya menjawab dengan satu kata saja dari apa yang dipaparkan guru. Pada saat wawancara, guru tidak cukup waktu untuk melatih secara khusus keterampilan sosial anak autis. Juga tidak ada waktu menerapkan model-model atau bentuk-bentuk materi bermain peran yang akan dilakukan oleh anak-anaknya di kelas ataupun di luar kelas. Sehingga anak-anak masih mengalami kesulitan untuk berkomunikasi dan berinteraksi. Begitu pula guru pendamping khusus hanya melatih anak dalam mengatasi kesulitan dalam berkomunikasi dan bersosialisasi. Karena guru pembimbing khusus belum sepenuhnya melatih anak dalam meningkatkan keterampilan sosial anak autis. Namun dalam pembelajaran guru pendamping khusus, selalu membimbing anak seperti berhitung, menulis, membaca, dan memecahkan masalah-masalah lainnya, sehingga dalam menyusun materi untuk bermain peran belum dilakukan oleh guru. Kadang-kadang dalam melaksanakan praktik bermain peran hanya dikakukan berdasarkan yang ada di dalam buku pelajaran saja. Sementara untuk mencapai keberhasilan dalam proses pembelajaran pada anak autis sangat ditentukan oleh kompetensi guru, termasuk kompetensi dalam mengembangkan keterampilan sosial. Guru kelas dan guru pendamping khusus sebagai pelaksana proses pembelajaran di sekolah dasar penyelenggara pendidikan inklusi merupakan fasilitator dan sekaligus pusat inisiatif bagi peserta didiknya atau siswanya. Maka dari itu, guru hendaknya selalu mengembangkan kompetensi baik kompetensi pedagogik, profesional, kepribadian, kepemimpinan maupun kompetensi sosial. Sangat penting bagi seorang guru agar mampu meningkatkan keterampilan sosial anak didiknya terutama keterampilan sosial anak autis. Karena guru merupakan bagian dari sosial dimana masyarakat sendiri adalah konsumen pendidik sehingga guru maupun warga sekolah harus mampu berkomunikasi secara baik dan efektif dengan masyarakat dan peserta didiknya sehingga dapat meniru apa yang dilakukan oleh gurunya. Apalagi anak autis sangant senang meniru apa yang diucapkan oleh guru dan temannya.

Melalui model bermain peran dalam meningkatkan keterampilan sosial yang dirancang pada penelitian ini akan memberikan kesempatan pada anak autis untuk mampu berkomunikasi dengan baik. Berinteraksi dengan lingkungan melalui lingkungan yang kondusif pula. Hal ini sesuai dengan yang dinyatakan Susan,et,al (2006) bahwa meningkatkan keterampilan sosial pada anak autis adalah sangat penting dilakukan dengan menggunakan bermain peran, karena kegiatan bermain peran tidak hanya dilakukan untuk berkomunikasi, akan tetapi juga melatih kepercayaan diri masing-masing anak yang melakukan akting dalam bermain peran.

4. Dukungan orang tua terhadap peningkatan keterampilan sosial anak autis

Dalam meningkatkan keterampilan sosial anak autis baik dalam berkomunikasi, berinteraksi dengan teman sebaya perlu kerja sama yang baik antara orang tua dengan guru ataupun dengan semua warga sekolah. Keraja sama antara orang tua dan guru disekolah murupakan hubungan yang bersifat kominikatif dimana guru sebagai pengajar ataua pendidik disekolah dasar dan orang tua sebagai pendidik dirumah harusnya selkalu berkomunikasi dengan baik agar semua permasalahan yang terjadi pada anak akan dapat terpecahkan agar potensi anak autis dapat berkembang dengan maksimal. Dalam hal ini komunikasi orang tua bersama guru memiliki tujuan agar orang tua dan guru dapat bertukar informasi yang berkaitan dengan dan permasalahan yang terjadi pada anak seperti anak sulit berkomunikasi, sulit berinteraksi dengan teman sebaya maupun orang lain. Guru berusaha meningkatkan kerja sama dengan orang tua dalam meningkatkan keterampilan sosial yang dinyatakan (Purwanto, 2007) antara lain: (1) Menghadiri setiap pertemuan orang tua dengan guru terutama pada hari penerimaan murid baru, perlu adanya kerjasama dalam menyelenggarakan pendidikan untuk anak autis melalui bermain peran agar anak dapat mencapai prestasi belajar yang diharapkan. (2) Selalu adanya informasi melalui surat menyurat antara guru dengan guru pendamping khusus agar dapat membantu proses pendidikan agar anak selalu mampu berkomunikasi (3) Orang tua selalu memperhatikan prestasi anaknya melalui nilai rapor setiap semester, (4) Guru melakukan kinjungan rumah orang tua dan sebaliknya kunjungan orang tua ke sekolah (5) 
Mengadakan pameran-pameran hasil karya anak di akhir semester, (6) Orang tua membuat perkumpulan atau biasa disebut juga dengan komite sekolah agar membantu memecahkan permasalahan di sekolah

\section{Kesimpulan}

Partisipasi setiap siswa dalam lingkungan sekolah inklusif membutuhkan keterampilan sosial yang baik, atau dalam istilah lain harus memiliki perkembangan sosial yang baik. Keterampilan sosial ini pun harus dimiliki oleh anak autis yang bersekolah di sekolah penyelenggara pendidikan inklusif sebagai prasyarat untuk mengikuti proses pendidikan yang dilaksanakan. Kondisinya, kemampuan sosial anak autis yang bersekolah di sekolah penyelenggara pendidikan inklusif di kota padang cukup beragam. Pengembangan keterampilan sosial anak autis sangat penting untuk dikembangkan melalui pembelajaran dan pendidikan yang dilaksanakan di sekolah. Kepala sekolah, guru kelas, guru pendidik khusus, dan orang tua memiliki pemahaman yang cukup baik untuk memahami anak autis, termasuk memahami keterampilan sosial anak autis di sekolah penyelenggara pendidikan inklusif. Alternatif pengembangan keterampilan sosial anak autis melalui metode pembelajaran bermain peran. Lingkungan sekolah sudah memiliki modalitas untuk melaksanakan pembelajaran bermain peran untuk mengembangkan keterampilan sosial anak autis.

\section{Daftar Rujukan}

Hardani, R. S., \& Rahmawati, S. (2007). Jurnal Keperawatan Soedirman (The Soedirman Journal of Nursing), Volume 2, No.1, Maret 2007. Prevention, 2(1), 17-23. https://doi.org/http://dx.doi.org/10.20884/1.jks.2013.8.2.470

Suryawati, I. G. A. A. (2010). Model Komunikasi Penanganan Anak Autis. Jurnal Ilmiah Fakultas Ilmu Sosial Dan Ilmu Politik, 1(1), $27-37$. 